\title{
MAPPING THE USABILITY AND QUALITY OF BICYCLE PATHS USING A TERRAIN- INCLINATION-BASED CLASSIFICATION, STUDY CASE: DARCY RIBEIRO CAMPUS, UNIVERSITY OF BRASÍLIA, BRAZIL.
}

\author{
Andrew Josengler de Siqueira ${ }^{1}$, Pedro Maragno do Almo ${ }^{1}$, \\ Rejane Ennes Cicerelli ${ }^{2 *}$, Raiane Francy Costa Machado ${ }^{2}$, Tati de Almeida ${ }^{2}$
}

\author{
${ }^{1}$ Instituto de Geociências, Universidade de Brasília, 70910900, Asa Norte, Brasília, Brasil - ajosengler, pedro.maragno5, \\ raiane.fmachado) @gmail.com \\ ${ }^{2}$ Instituto de Geociências, Universidade de Brasília, 70910900, Asa Norte, Brasília, Brasil - (rejaneig, tati_almeida) \\ $@$ @unb.br
}

\begin{abstract}
Over the last decades, Brazilian cities have gone through a rapid process of urbanization. Population growth has brought the need for new technological and construction developments such as highways and housing centers. One of the most important factors related to this growth has to do with the capacity of locomotion, which is done especially by car. In Brasilia there is a large volume of cars circulating, which causes noise, air pollution, difficulty of locomotion during rush hours generated by traffic jam and stress that affects drivers and the general population. The bike stands out in this context because it is a vehicle considered clean for not polluting the environment-and it is easily accessible to almost all social classes, being ideal for short to medium range routes. The University of Brasilia (UnB) has a considerable number of cyclists. The University has several bike lanes that have been built to connect the various departments along the campus. In this context, the purpose of this work is the elaboration of a slope map made from a Digital Elevation Model (DEM) to classify the bike lanes as critical or not. The DEM was made from a rectangular grid by the Anudem method and a final map in the 1: 10000 scale was generated. The proportion of green areas and lampposts that cover the bike lanes on campus was also analyzed. The results characterize the bike lanes as non-critical in relation to the inclination, whereas the relation of number of lampposts as well as the vegetation that cover the area to the number of bike racks on campus was considered low.
\end{abstract}

KEY WORDS: Bicycle path, DEM, slope, GIS, Brasilia

\section{INTRODUCTION}

The Urban mobility, throughout the twentieth century, was fundamental for the development of Brazilian cities and today is something essential in daily life, as they interfere with the quality of habitant's life who depend on their routine movement (CARVALHO, 2008). In recent decades, there has been an intense increase in the use of motor vehicles and the implementation of highways, so that their circulation can be possible. Thus, large urban centers have been configured to support vehicle traffic without considering pedestrian mobility and other means of transportation such as bicycles. Issues intrinsically related to urbanization such as mobility, solid waste management and sanitation are included in the 2030 Agenda for Sustainable Development (Goal 11) proposed by the United Nations.

Significant changes in the construction and management of urban spaces model is essential to achieve sustainable development. Even in planned cities like Brasilia there has been an unbridled growth around them. Real dormitory cities have sprung up, whose inhabitants need to travel during the day to the big centers to work, and at night they return to their homes (MIRAGAYA, 2013), using cars and public transportation to get around such as buses and subways, which, besides being scarce, suffer from overcrowding. With the rise of debates about sustainable development and in view of the harms generated by motor vehicles, such as noise, air pollution and the stress caused by car traffic congestion, the incentive to study and implement projects aimed at sustainability in urban areas has grown. This factor contributes to promote the equity in urban spaces, social inclusion and environmental preservation. In this context, the bicycle stands out.

During this work, it was chosen as a case study the cycling network of the city of Brasilia-DF at the University of Brasilia located in Asa Norte, which presents problems of urbanization and infrastructure due to its rapid growth. Being an institutional hub, there is a large circulation of cars and people, which demands a better organization in its infrastructure. According to the Statistical Yearbook of the University of Brasilia, the number of people institutionally linked to the University in 2017, being undergraduate, postgraduate students, faculty and administrative technicians is 53,657 , a number that draws attention to the encouragement of public policies in Brazil (FUB, 2018). The planning of the bicycle district network of the Federal District began in 2003 with the creation of the Secretariat of Sustainable Urban Mobility (SeMob) and its construction began in 2006, from Lago Norte to Varjão, with a partnership between DER-DF, University of Brasilia and the NGO Rodas da Paz (VELLOSO, 2015). This implementation was an attempt to reduce the number of cars in this region and consequently the number of accidents between cyclists and drivers. Brasilia's cycling network is undergoing constant changes and currently works as a facilitator of urban transport.

For the development of this project, a crucial part is the geographic representation of the surface and objects present in the study area. To achieve this objective the Geographic Information System (GIS) was used. This system basically functions as a representation joining and editing the associated numerical data with a geographic component. In this work, GIS tools were useful because it allowed us to quantify and classify parts of a region according to attributes previously defined as of the interest of this work. The objective of this work is to analyze slope parameters, illumination, green areas in the University of Brasilia cycle path and thus classify the slope of the bike paths as critical or not. The tools used were those of geoprocessing as Digital Elevation Model (DEM).

\section{METODOLOGY}

A bibliographic search was performed in order to find limit values of longitudinal slopes. According to SIMEÃO et al. (2019), a slope limit and the road length was compared using the CROW and AASHTO manuals. From these manuals, it was observed that roads longer than $100 \mathrm{~m}$ had slopes between $4.5 \%$ and $8 \%$. Parts of the bike path that have altitude changes 
are approximately $200 \mathrm{~m}$, a slope of $5 \%$ was chosen as the standard for analysis. Thus, roads with slopes below or equal to $5 \%$ were classified as non-critical and roads with slopes greater than $5 \%$ were classified as critical.

The data of the cycle path (extension, location, bike paths) and motorways were obtained from the georeferenced data available on the geoportal called SEDUH - DF (from portuguese Secretaria de Estado de Desenvolvimento Urbano e Habitação). The bicycle path data was obtained from the Google Maps ${ }^{\circledR}$ platform and the lighting and vegetation cover data were obtained from the institutional database of the University of Brasilia. This data is given in shapefile format in the scale 1: 10000. Figure 1 shows the location of the studied area and represents the cycling network of the University of Brasília in the Asa Norte region.

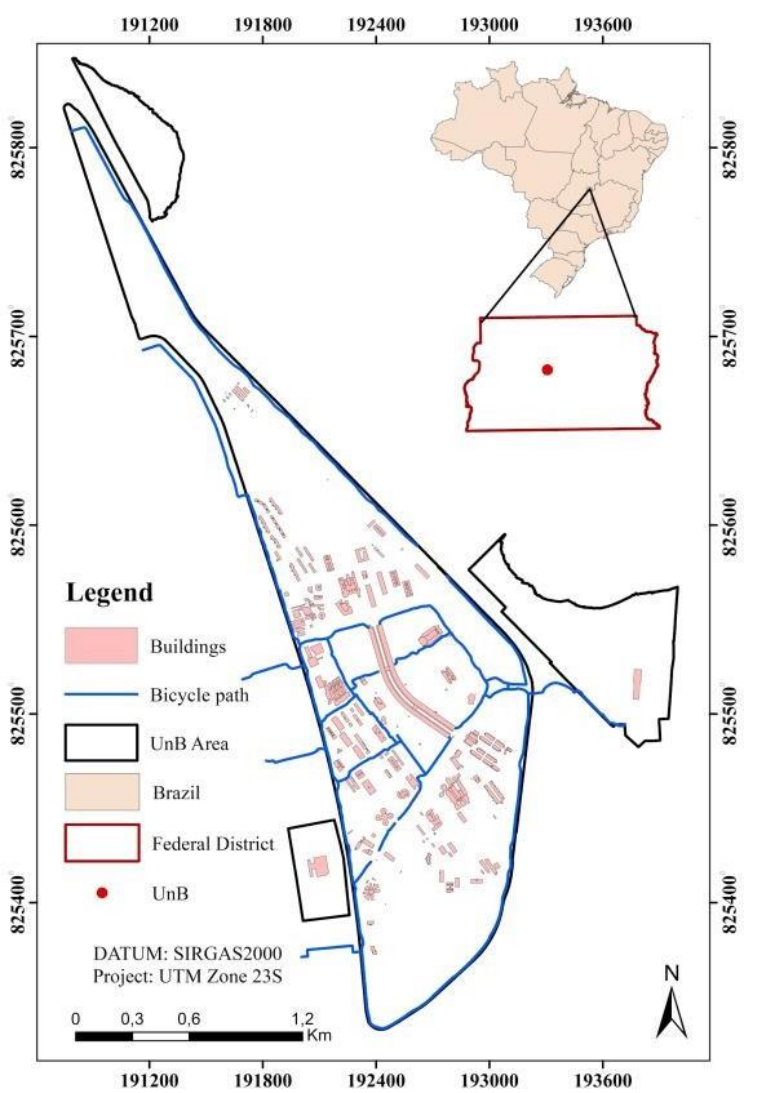

Figure 1: Map of the cycling network of the University of Brasília Source: The Authors

The slope determination was made from a digital elevation model that was produced using a database of $1 \mathrm{~m}$ interval level curves arranged in a vetorial format (SEDUH, 2019). For the generation of MDE the software used was the ArcMap from ESRI, version 10.6.1.

The MDE was generated from a rectangular grid using the Anudem method (Hutchinson, 1988), which consists of an interpolation technique to generate a matricial file from points and contours. (Câmara \& Monteiro, 2001).

Generating the MDE, the altimetric regions were characterized as a function of color as shown in Figure 2.

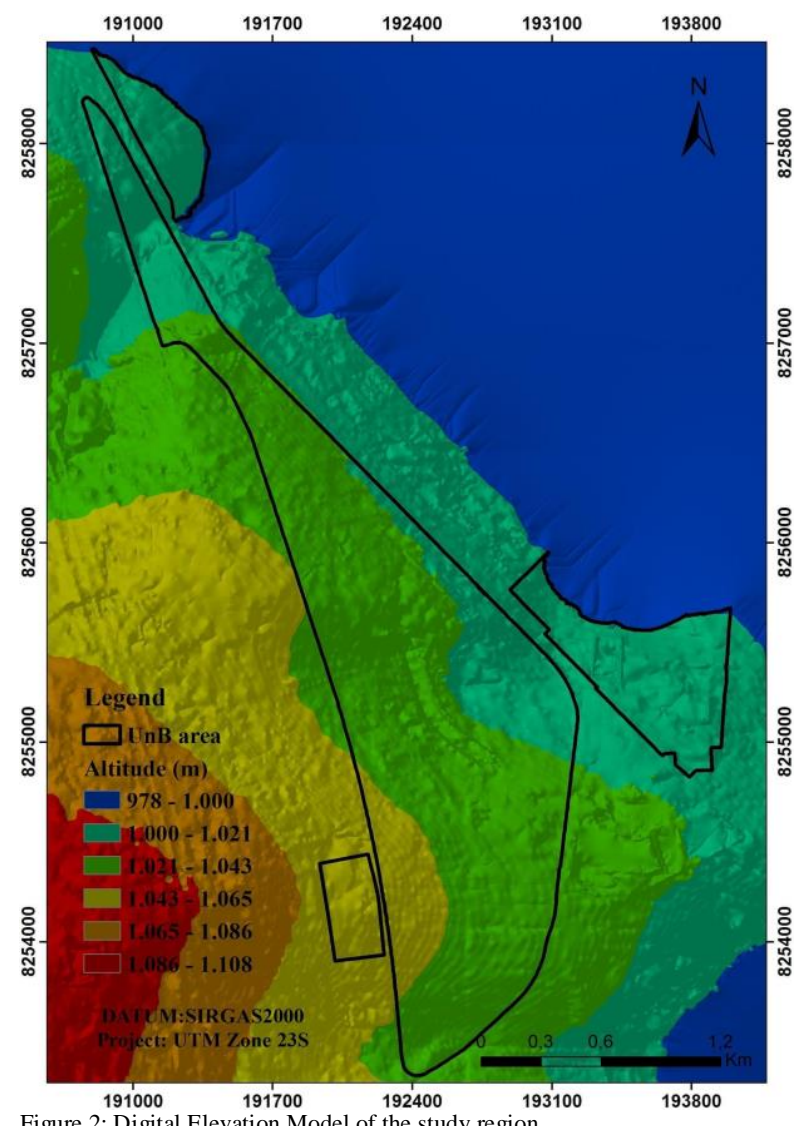

Figure 2: Digital Elevation Model of the study region

Source: The Authors

The flowchart with the main steps of the methodology is shown in Figure 3.

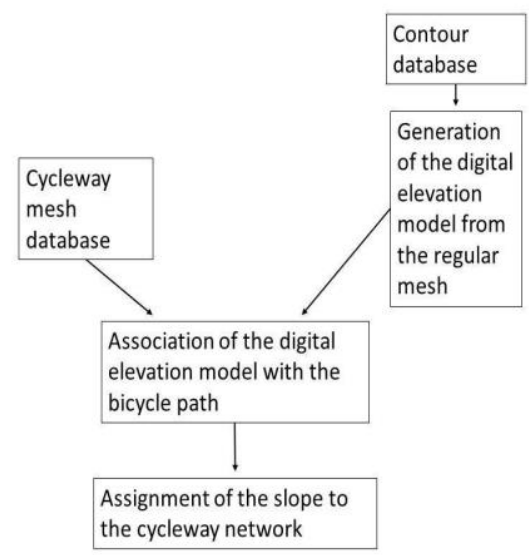

Figure 3: Activity flow chart

Fonte: The Authors

\section{RESULTS}

Mapping $16.667 \mathrm{Km}$ of bike paths on the UnB campus, it was found that only $3.059 \mathrm{Km}(18.35 \%)$ of the total length has vegetation cover, a factor that can cause stress and tiredness to users on hot days as well as direct sun exposure, which can come to be harmful to health. Only a length of 2.905 $\mathrm{km}(17.43 \%)$ has streetlight at a distance of at least $15 \mathrm{~m}$ from the bike path. This value for a campus is low considering the movement of students at night, who may have sight and safety impaired due to darkness. Sixty-four crossings with motorways were accounted for, eight of them with a high flow road. This result may help in the improvement of high flow road signaling. 
When it comes to the slope of the bike path, most of it has a slope between $0 \%$ to $5 \%$ and the rest is within the range of $5 \%$ to $25 \%$ with no slope greater than $25 \%$.

Other relevant points are the presence of 54 bike racks with 3 to 62 parking spaces available per bike rack. The largest is located near the Central Library (ECB) and 5 shared bike racks are located nearby: the Central Science Institute (ICC), the Olympic Center (CO), the Arts Institute, the ECB and the Anísio Teixeira Pavilion (PAT). Figure 4 below represents the cycle path with the critical and non-critical sections and Figure 5 and 6 represent the maps containing vegetation cover data, lighted stretch, bicycle parking spaces and intersections between bicycle path and motorway routes.

The data obtained is of relevance to cyclists and pedestrians who attend the campus as it serves as an informative content that can help to make the most comfortable route according to the parameters shown on the map. In order to bring this information to everyone on campus, it is important that the map to be digitally and physically distributed along with the numerical data. This will make it possible for the map to be viewed by higher government agencies, so that public policies can be implemented to improve urban mobility in this region.

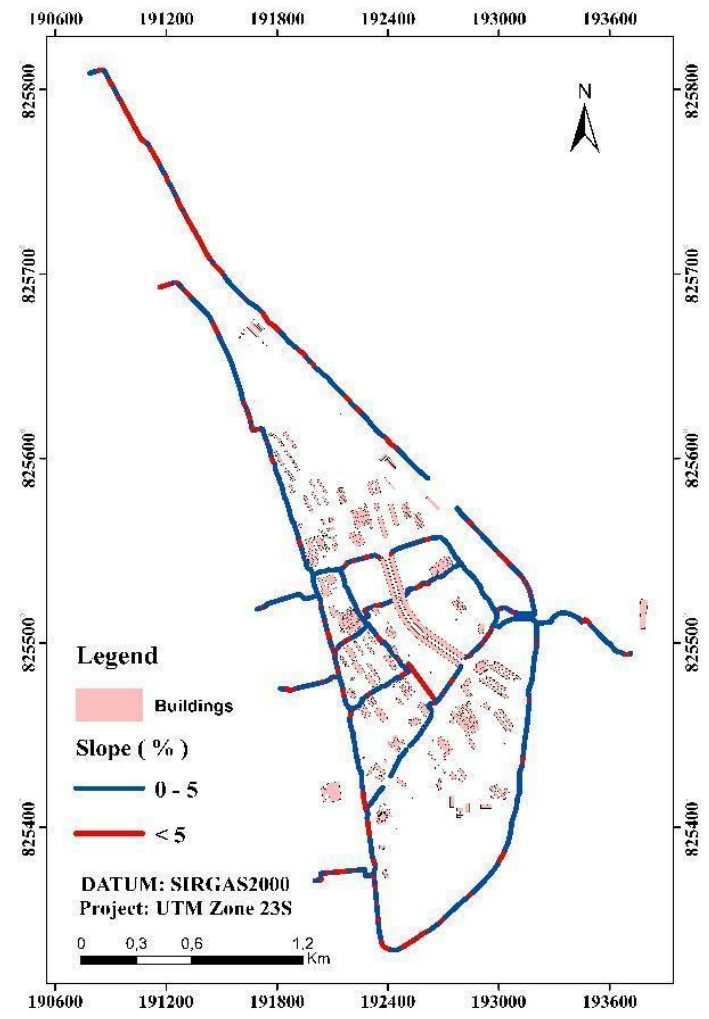

Figure 4: Bicycle path slope map Source: The Authors

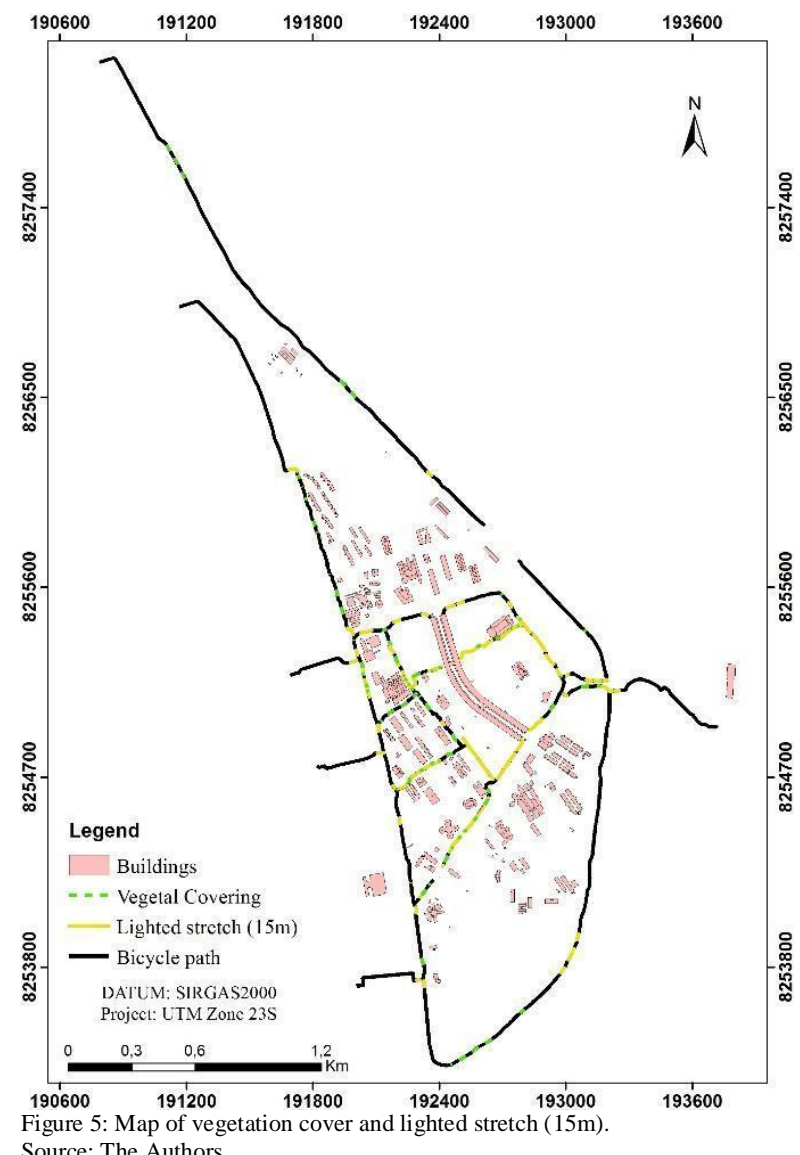

Source: The Authors

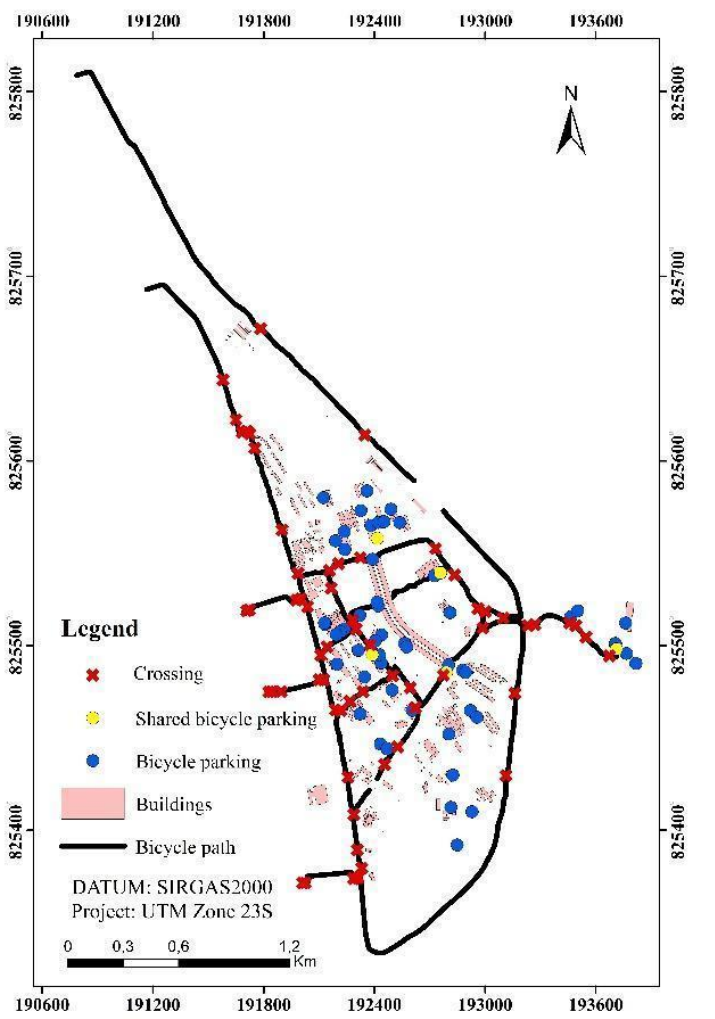

Figure 6: Map of crossing, shared bicycle parking and bicycle parking. Source: The Authors 


\section{CONCLUSIONS}

The uses of the DEM together with the interpolation techniques were fundamental to reach the obtained results, which were consistent with the research objective. It is noteworthy that from these results it can be seen that the University of Brasilia bicycle path is generally composed of slopes below $5 \%$, presenting no risks, a factor that contributes to the circulation of cyclists. It is noted that the coverage of green areas and street lighting is $18.35 \%$ and $17.43 \%$ respectively of the bicycle path, a very low value considering the amount of bicycle parkings and shared bicycle parkings existing on campus to meet the demand of students who ride bicycles.

To improve the quality and increase the volume of data within this work, it is suggested to count the number of cyclists attending the study site, as well as a cyclist satisfaction survey as a form of validation.

Even without the data from cyclists who attend the desired place of study, it is possible to obtain a great result using the method presented, which can be used anywhere in the world relying only on data of slope, extension and location of the bike path, vegetation cover, lighting poles, bicycle parkings and motorway routes, most of which is easily obtained using remote sensing techniques.

The Digital Elevation Model tool is a very useful feature for slope analysis. It can be applied in a larger scale, such as the Federal District, requiring only contour data and the cycling network.

\section{BIBLIOGRAPHY}

Câmara, G. \& Monteiro, A. M. V. (2001). Conceitos básicos em ciência da geoinformação. Em Câmara, G., Davis, C. \& Monteiro, A. M. V. (Orgs). Introdução a Ciência da Geoinformação (pp. 7-42). São José dos Campos, INPE.

Carvalho, D. L. Mobilidade urbana e cidadania no Distrito Federal: um estudo do Programa Brasília Integrada. Soc. Estado, Vol 23, $\mathrm{n}^{\circ} 2$, p. 497-498. Brasília, 2008. http://dx.doi.org/10.1590/S0102-69922008000200017.

FUNDAÇÃO UNIVERSIDADE DE BRASÍLIA. Anuário Estatístico da UnB 2018. Disponível em: http://www.dpo.unb.br/images/phocadownload/unbemnumeros/ anuarioestatistico/Anurio_Estatstico_2018.pdf

Hutchinson, M. F. (1988), "Calculation of hydrologically sound digital elevation models", in Proceedings of the Third International Symposium on Spatial Data Han-dling, 17-19 August, Sydney, Australia, International Geographical Union, Ohio, pp. 117-133.

Miragaya, J. (2013). Perfil da Distribuição dos postos de trabalho no Distrito Federal: Concentração no Plano Piloto e déficits nas cidades-dormitório. Brasília: Companhia de Planejamento do Distrito Federal. Dísponível em: http://www.codeplan.df.gov.br/wpcontent/uploads/2018/02/Perf il-da-Distribui\%C3\%A7\%C3\%A3o-dos-postos-de-Trabalho noDF-Concentra\%C3\%A7\%C3\%A3o-no-Plano-Piloto-e-Deficits nas-Cidades-Dormit\%C3\%B3rio.pdf.

Secretaria de Desenvolvimento Urbano e Habitação. Geoportal: Infraestrutura de Dados Espaciais -IDE/DF, 2019. Página Inicial. Disponível <https://www.geoportal.seduh.df.gov.br/mapa/>.

Simeão, J. V.; Manzato, G. \& Viviani, E. Recursos de Geoprocessamento Aplicados à Análise da Declividade da Malha
Cicloviária da Cidade de São Paulo. Revista Brasileira de Cartografia, vol. 71, n. 1, janeiro/março, 2019. pp. 253 - 273.

Velloso, M.S. (2015). Programa Cicloviário do DF: passado, presente e futuro. Brasília: Companhia de Planejamento do Distrito Federal. Disponível em: http://www.codeplan.df.gov.br/wpcontent/uploads/2018/02/TD_2_Planejamento_Ciclovi\%C3\%A 1rio_no_DF.pdf. 